\title{
The Development of Montessori-Based Javanese Script Learning Model
}

\author{
Joko Sukoyo $^{1 *}$, Esti Sudi Utami ${ }^{2}$, Endang Kurniati ${ }^{3}$ \\ Language and Art Faculty, Universitas Negeri Semarang, Semarang, Indonesia ${ }^{123}$ \\ j_sukoyo@mail.unnes.ac.id
}

\begin{abstract}
The emerging problems dealing with learning Javanese script are conventional learning methods applied by teachers, lack of innovative learning, and less motivated learners to learn Javanese script. One of the solutions for the problem is developing a Montessori based learning model. It has several strengths compared to other methods, such as a joyful learning approach by playing a game and applying interesting media. This is an ADDIE Research and Development study with the following stages: analyze, design, develop, implement, and evaluate. The result was a product of the Montessori-based Javanese script learning model. The model components are syntagmatic, social system, supportive system, reaction principles, instructional impacts, and accompaniment impacts. Syntagmatic consists of the learning model implementation stages. They cover the introducing stage, recognize Javanese script, recall Javanese script, mention Javanese script, write words, read words, assess, and close. The social system consists of Joyful learning principles and asah (activity to train the learning material mastery skill), asih (activity that shows compassion), asuh norms (a kind, patient, and sensitive learning approach toward the engaged events). The model reaction principle puts teachers as directors, planners, observers, and evaluators. The supportive model system consisted of interesting learning media. Meanwhile, the instructional impacts dealt with the joyful, comfortable, and relaxing learning atmospheres and activities.
\end{abstract}

Keywords: model, learning, Javanese script, Montessori

\section{INTRODUCTION}

The actual realization showed that the Javanese script learning had not been maximally promoted because of various problems either from teachers' and learners' sides. One of the problems from teachers' perspectives is - the use of conventional learning methods [1], the tendency to apply the lecturing method [2], and the lack of innovative, interactive, and modern learning media. Thus, it made the learning process had less teacher-learner interaction. On the other hand, based on the learners' perspectives, they were not motivated to join Javanese script learning, had difficulties in memorizing and differing the carakan (letter of the alphabet), pasangan (pair), and sandhangan (attribute) scripts [3]. Therefore, a proper solution is needed. One of the solutions is by applying a Joyful based learning method. One of its realizations is the Montessori method implementation in learning.

The Montessori method is a preferred method by Indonesian people these recent years. Most educational institutions even take the word to attract parents to send their children to learn at their institutions [4]. This method is developed by Maria Montessori. She is a scientist and an Italian doctor. This method facilitates learners to succeed. They are given opportunities to be more literate by introducing materials in the first place for the learners [5]. The applied learning methods are reading, writing, and calculating. Dealing with reading and writing, Montessori found that writing should be immediately taught for the learners before reading [6].

Reading and learning activities under the Montessori method are different from the common reading and writing activities. The differences are: (1) children are not directly given writing tools to use on books. However, they are introduced with pre-writing and pre-reading. For example, they play a game or sing a phonic song for the first time. (2) Montessori learning uses meaningful words to learn. For example, by teaching vocabularies such as "hands", "eyes", and "ears" instead of "ba-bi-bu", "na-ni-nu", and "ta-ti-tu". (3) children are introduced to several matters that started from concrete until abstract matters.

This method has superiorities to typical methods. The strengths points of this method are joyful and interesting. The learners could play games and have interesting learning media such as wooden or paper word cards as the learning media. Montessori learning respects children's differences. It also could develop the social and emotional skills of children. 
Several studies also concluded that the Montessori method was effective for learning [7]; [8]; [9]. From the explained strengths, this research developed a Montessori-based Javanese script learning model.

\section{METHODOLOGY}

\subsection{Research Design}

The applied research and development model is a model proposed by Robert Maribe [10]. It offers a developmental model named ADDIE. The stages are (1) analyzing, (2) designing, (3) developing, (4) implementing, and (5) evaluating.

\subsection{Data and Data Source}

Two data sources were used for this research. The first data dealt with teachers' necessities about the Montessori-based Javanese script learning model for reading and writing. The second data was model prototype validation from experts. The data source consisted of the teachers, the Javanese script expert, and the Montessori learning expert. The teachers functioned as the data sources of necessity analysis while the Javanese script and Montessori learning experts as the developed model data validation source.

\subsection{Data Collection Technique}

The applied data collection techniques were interviews and questionnaires. The interview technique was used to obtain data analysis of the learning model necessity. It was done for the Primary School Javanese language teachers. On the other hand, the questionnaire consisted of learning model necessity analysis and the Montessori-based Javanese script learning model expert validation questionnaire.

\subsection{Technique of Analyzing Data}

The technique of analyzing data consisted of prototype necessity analysis and expert validation analysis. The prototype analysis consisted of data reduction, display, conclusion, and verification [11]. The expert validation analysis technique was done by presenting the learning model development to the experts, attached by the assessment rubric sheet. The judgment of the experts was analyzed. The percentage and average scores were analyzed, and then the prototype model would be revised.

\section{FINDING AND DISCUSSION}

\subsection{The Teachers' Necessity Analysis toward Montessori-based Javanese Script Learning Model}

This data analysis was obtained from the questionnaire. The necessity analysis applied a theory [12]. The analysis should cover the necessities, want, and lack.

Table 1 The Teachers' Necessity Analysis toward the Developed Model

\begin{tabular}{|c|c|}
\hline Aspects & Necessities \\
\hline \multirow[t]{2}{*}{ Necessities } & Learning reading and writing Javanese script were required to preserve the Javanese language. \\
\hline & Learning, reading, and writing Javanese script were required as a cultural icon. \\
\hline \multirow[t]{3}{*}{ Wants } & Learning reading and writing Javanese script were designed by the Montessori method. \\
\hline & The needed assessments were written, project, and portfolio assessments. \\
\hline & The needed learning media were Javanese script media such as video or audio. \\
\hline \multirow[t]{2}{*}{ Lack } & $\begin{array}{l}\text { The assumed difficult materials were legena (letter of the alphabet), pasangan (pair), and } \\
\text { sandhangan (attribute) } \\
\text { of the script. }\end{array}$ \\
\hline & $\begin{array}{l}\text { The learners' problems were, such as feeling difficult to memorize the script letters, memorizing } \\
\text { them but having untidy writing realization, being influential to read the script, writing but taking } \\
\text { a long time, and lacking attention during the teacher's explanation. }\end{array}$ \\
\hline
\end{tabular}

\subsection{Montessori-based Javanese Script Learning Model Prototype}

A learning method is a scaffolding that consists of learning stages. They are planned from the beginning until the learning ending [13]; [14]. The model's components are syntagmatic, social system, supportive system, reaction principles, instructional impacts, and accompaniment impacts [15].

\subsubsection{Montessori-based Javanese Script Learning Model Syntagmatics}

Syntagmatic is the learning activity order of a learning model. The learning model syntagmatic consists of: 1. Preliminary Stage 
Learning is started by a greeting or introduction activity to explain the core competence to learn, its learning objective, the learning material, the lesson's use, and the learning procedure. This stage is the beginning stage for learners to prepare themselves following the lesson.

2. Javanese script introduction

They were introduced by Javanese script assisted by sandpaper letters. Sandpaper letters are embossed and sandpaper textured letters so that learners could palpate it with their fingers. The learners palpated the script on the sandpaper letters based on the writing methods. When the learners palpated the scripts, they had to also pronounce the sound.

3. Remembering the Javanese script.

Learners had time to memorize the scripts. The teachers did not have to share all Javanese scripts, 20 letters. However, teachers could do it gradually, started by having five or ten letters first. It had a purpose to reduce the learners' burdens to learn the script.

4. Mentioning the Javanese script

In this stage, teachers put several scripts in front of the learners. The learners were then asked to mention the scripts. If the learners had not memorized it, the teachers had to repeat it. Teachers were not allowed to share punishment when learners had not memorized the scripts. Teachers should avoid direct assistance, but they could encourage learners to be aware of their mistakes (self-correcting).

5. Writing words

Besides sandpaper letters, other media of the Montessori model is a large movable alphabet. It has a different function from sandpaper letters that were used to introduce the script. This large movable alphabet was used to construct words. A large movable alphabet is built from wood or other solid material. Thus, learners would surely be aware of the script forms. With this media, learners could arrange a word and put it in one line.

6. Reading the words

The applied media was pictorial or word cards, also known as vocabulary cards. It became the media for learners from concrete matters into abstract matters. In this stage activity, the teacher asked learners to match a vocabulary card to the appropriate picture. For example, learners selected two vocabulary cards baya (crocodile) and naga (dragon). The teacher described these and asked learners to read aloud and took the matched pictures, crocodile, and dragon pictures.

7. Writing sentence stage

The teacher made three boxes: subject, predicate, and object boxes. The subject box would be filled with words functioning as the subject of the sentence. Then, the words were colored red. The predicate box would be filled by words functioning as predicates. Then, the words were colored green. The object box would be filled with words functioning as the object of the sentence. Then, the words were colored blue. Teachers asked learners to read the words then selected one word from the subject box, a word from the predicate box, and a word from the object word. Eventually, they put the words on a table and arranged them as a sentence with subject, predicate, and object order. The teacher monitored the learners and ensured that they could arrange sentences correctly and reliably. In the next stage, the teacher asked them to write Javanese scripted sentences on paper.

8. Reading the sentence

In this stage, the teacher took two pictures containing simple activities; for example, a man is eating, an old brother is studying, etc. Then, the teacher described the pictures and put them in front of the learners. The teacher took two cards containing two sentences about the pictures. Then, learners were asked to read aloud the Javanese scripted sentences, take them, and put them next to the pictures. If the learners still committed mistakes, the teacher should help them. It should not directly be given, but it had to encourage learners to find their mistakes (self-correcting).

9. Assessment

The applied assessment techniques of this model were observation and test.

10.Closing

This activity provided a full description of what the learners had learned, the learners' achievements, and the success levels of the teacher's teaching. The teacher ended the learning by asking learners to recall what they had learned. The teacher asked the learners' opinions about the learning activity. Then, he said their gratitude and asked the class leader to start leading the prayer.

\subsubsection{The Social System of Montessori- based Javanese Script Learning Model}

A social system refers to the applied norms and principles in the learning model. The applied principle in learning was joyful learning. It referred to a joyful learning atmosphere with asah, asih, and asuh norms. Asah refers to an activity to train the learning material mastery skill. Asih refers to an activity that shows compassion, either compassions between students and teachers or teachers and students. Meanwhile, asuh refers to a kind, patient, and sensitive learning approach toward the engaged events. 


\subsubsection{The Reaction Principle of Montessori- based Javanese Script Learning Model}

A reaction principle is an activity pattern describing how a teacher should treat his students, including how they should respond to what a student does. In this learning, the teacher had a role as a director, an observer, and an evaluator.

\subsubsection{The Social System of Montessori- based Javanese Script Learning Model}

A supportive system is anything used to support achieving the learning objectives. The social system of this learning model consists of a learning environment and media. The Montessori learning environment is designed to support constructive learning and develop learners' physical, mental, and spiritual aspects. Then, the applied learning media were sandpaper letters and a large movable alphabet. It has a different function from sandpaper letters that were used to introduce the script. This large movable alphabet was used to construct words. A large movable alphabet is built from wood or other solid material. Thus, learners would surely be aware of the script forms.

\subsubsection{The Instructional and Accompaniment Impacts of Montessori-based Javanese Script Learning Model}

The instructional impacts are the direct impacts of a learning activity. Meanwhile, the accompaniment impacts are additional effects obtained by students during a learning process. The instructional impacts were such as joyful, comfortable, and relaxing learning atmospheres. Meanwhile, the accompaniment impacts were learning how to understand individual differences, developing problem-solving skills, and developing communication skills.

\section{CONCLUSION}

The model's components are syntagmatic, social system, supportive system, reaction principles, instructional impacts, and accompaniment impacts. The Montessori-based Javanese script learning model has a constructivist paradigm. It used an individual approach and combined academic and social educations. This model makes learners curious and uses games as a method to activate learners. The Montessori model has a philosophy to start learning from concrete until abstract matters, from easy things into a more complex matter, and to repeat the activity until learners master it.

\section{REFERENCES}

[1] Y. F. Avianto and T. A. S. Prasida, "Pembelajaran Aksara Jawa Untuk Siswa Sekolah Dasar Dengan Menggunakan Media Board Game," Aksara, vol. 30, no. 1, p. 133, 2018, doi: 10.29255/aksara.v30i1.223.133-148.

[2] S. Suwarsi, "Meningkatkan Kemampuan Membaca dan Menulis Aksara Jawa Melalui Metode Drill," Eduscope, vol. 1, no. 1, 2015.

[3] O. Suria, "Development of Word Game Algorithm for Learning Javanese Script," CommIT Journal, vol. 12, no. 2, pp. 73-86, 2018.

[4] S. Elytasari, "Esensi Metode Montessori dalam Pembelajaran Anak Usia Dini," J. Arraniry, vol. 3, no. 1, pp. 59-73, 2017.

[5] T. Ryan, "The Importance of writing before reading; How Montessori materials and curriculum support this learning process," pp. 144, 2015.

[6] M. Montessori, The Discovery of the Child. New York: Random House Publishing Group, 1967.

[7] J. D. Mallett and J. L. Schroeder, "Academic Achievement Outcomes: Montessori and NonMontessori Public Elementary Students," J. Elem. Educ., vol. 25, no. 1, pp. 39-53, 2015

[8] I. Firdaus, "the Application of Montessori Method To a Child'S Development in English Reading and Writing Skills (Case Study)," Pujangga, vol. 3, no. 2, p. 35, 2018, doi: 10.47313/pujangga.v3i2.439.

[9] J. Dhikska and K. Shivakumara, "The effect of Montessori and trafitional methods of education on emotional intelligence of children," Eur. J. Educ. Stud., vol. 3, no. 4, pp. 367-382, 2017, doi: 10.5281/zenodo.399050.

[10] R. M. Branch, Instructional Design: The ADDIE Approach. New York: Springer, 2009.

[11] M. Miles and A. Huberman, Qualitative Data Analysis. London: Sage Publication, 1994.

[12] J. Macalister and I. S. Nation, Language Curriculum Design. New York: Routledge 270 Madison Ave, 2010.

[13] A. T. Setiawan and D. Handayani, "Model pembelajaran berbasis permainan tradisional ancak-ancak alis sebagai pemerkuat karakter bangsa di era aec," Prosiding Seminar Nasional Pendidik. Universitas Muhammadiyah Sidoarjo, pp. 58-71, 2017.

[14] A. Majid, Strategi Pembelajaran. Bandung: PT Remaja Rosdakarya, 2016.

[15] B. Joyce, M. Weil, and E. Calhoun, Model of Teaching. New Jersey: Pearson Education, 2009. 